\title{
USE AND CONSERVATION OF VANILLA PLANIFOLIA J. IN THE TOTONACAPAN REGION, MÉXICO
}

\author{
BRAULIO EDGAR HERRERA-CABRERA ${ }^{1, *}$, VICTOR MANUEL \\ SALAZAR-ROJAS ${ }^{1,2}$, ADRIANA DELGADO-ALVARADO ${ }^{1}$, \\ JORGE CAMPOS-CONTRERAS ${ }^{2}$, and JUANA CERVANTES-VARGAS ${ }^{1}$
}

\footnotetext{
${ }^{1}$ Colegio de Postgraduados en Ciencias Agrícolas - Campus Puebla, Programa de Estrategias para el Desarrollo Agrícola Regional. Km. 125.5 Carr. Fed. Méx.-Pue. Col. La Libertad. Puebla, Pue, Mexico.

${ }^{2}$ Universidad Nacional Autónoma de México - Unidad de Biología, Tecnología y Prototipos (UBIPRO),

Facultad de Estudios Superiores, Iztacala. Av. De los Barrios No. 1, Los Reyes Iztacala, Tlalnepantla Edo. de México

*Corresponding author: braulio_edgar@hotmail.co.uk; behc@colpos.mx
}

\begin{abstract}
The use and conservation of Vanilla planifolia Jack. in Mexico requires comprehensive and detailed analysis of its genetic variation and of the issues that determine it. For this reason, we studied the variation in phytochemical contents that define vanilla aroma quality by HPLC (High Performance Liquid Chromatography) to identify genetic variation at the infraspecific level among 14 microsatellite loci and to study assessment criteria which determine the attitude of stakeholders regarding use and conservation of vanilla germplasm in the Totonacapan region, Mexico. To this end we used the multi-attribute analysis method, AHP (Analytic Hierarchy Process). The results showed the existence of six phytochemical groups (chemotypes) within V. planifolia germplasm, each with specific aromatic characteristics. The 14 loci analyzed were polymorphic for vanilla chemotypes with variable sizes, and genetic clustering of accessions coincided with phytochemical grouping (chemotypes). It was noted that the process of economic and cultural valuation of users has caused aromatic variation in vanilla germplasm, and this variation has been conserved at the regional level. Thus, the data indicate that in the probable center of origin of vanilla there is genetic and phytochemical variation, knowledge of which is fundamental to the design of breeding programs to optimize the benefits of vanilla production for stakeholders and to contribute to the conservation of the primary gene pool of Vanilla planifolia.
\end{abstract}

Keywords: Vanilla aroma, chemotypical variation, genetic variation, social valuation

\section{Introduction}

Mexico is recognized as center of origin of Vanilla planifolia G. Jack. (Soto-Arenas 2003; Verpoorte 2011), particularly, the Totonacapan region, which possesses germplasm of greatest importance both biologically and commercially. However, the available information regarding the phytochemical and genetic characteristics that define its aromatic quality is scarce.

Moreover, two factors related to the use and conservation of vanilla in the Totonacapan region have been identified. The first factor, linked to conservation, comprises two elements: the lack of knowledge of genetic variation of vanilla germplasm (Soto-Arenas 2006; Minoo et al. 2006) and the fact that both wild and cultivated populations are highly vulnerable to factors such as genetic erosion related to the clonal characteristic of the population, over-collection of wild specimens and destruction of their habitat by human and meteorological phenomena (Lubinsky 2003), which put them in danger of extinction. The second factor is associated with underutilization of vanilla germplasm. Despite the fact that it is the center of origin, Mexico contributes less than $1 \%$ of the world vanilla production (Soto-Arenas 2006). This has been attributed to problems of quality, which is heterogeneous; vanillas of different aromas and of high and low quality are mixed, having a direct negative impact on the market and price, on system stakeholders, and on conservation of the region's germplasm.
Ignorance of the diversity of the biological material makes it difficult both to undertake conservation actions and to improve quality by enhancing quality traits that would benefit stakeholders of this genetic resource. This study was conducted to characterize vanilla germplasm of the Totonacapan region, Mexico, phytochemically, genetically and socioculturally and, with this characterization, to design strategies of use and conservation integrating the traits that define commercial quality in vanilla, genetic variation of the germplasm, and the use and valuation systems of stakeholders.

\section{Materials and methods}

The study was structured in four phases:

\section{1) Analysis of chemotypical variation of Vanilla planifolia germplasm}

HPLC analyses were performed on processed pods from 25 vanilla accessions. The pods were the product of flowers pollinated manually during the last week of April and the first week of May, 2007. They were harvested 28 weeks later and subjected to traditional processing, which lasts 14 weeks. In this way, there was control over fruit maturity, processing method, storage conditions, storage time, and extraction method, all of which are rec- 
ognized as factors that affect the quality of vanilla aromatic compounds (Sharma et al. 2006). With control over these factors, we aimed to determine phytochemical variation attributable to two sources: geographic origin or collection.

The content of four main phenolic compounds that give vanilla its aroma were assessed: $p$-hydroxybenzoic acid (C1), vanillic acid (4-hydroxy-3-methoxybenzoic acid) (C2), p-hydroxybenzaldehyde (C3) denominated minor compounds (MC) because they are found at concentrations below 2000 ppm, and vanillin (4-hydroxy-3methoxybenzaldehyde) (C4), which is the most abundant compound (around $20000 \mathrm{ppm}$ ). These four phenols are recognized as principal compounds contributing to vanilla aroma, because of their high concentrations (Wescott et al. 1994; Sostaric et al. 2000; Sharma et al. 2006).

Extracts were injected into the HPLC apparatus (Perkin-Elmer Series 200) under the following conditions: the analytical column was a RP-18 Spheri-5, injection volume: $20 \mu \mathrm{l}$, flow: $1.5 \mathrm{ml} \mathrm{min}^{-1}$, mobile phase: $25 \%$ methanol, $75 \%$ phosphoric acid, and run time: $20 \mathrm{~min}$.

\section{2) Analysis of infraspecific genetic variation of Vanilla planifolia}

We analyzed 14 microsatellite loci for $V$. planifolia. Amplification of the fragments was conducted in a Thermocycler Gene Amp PCR System 9700 under the following parameters: an initial step of $4 \mathrm{~min}$ at $94{ }^{\circ} \mathrm{C}$, 34 cycles of $30 \mathrm{~s}$ at $94^{\circ} \mathrm{C}, 45 \mathrm{~s}$ at $50-53^{\circ} \mathrm{C}$ (hybridization temperature was reduced by $0.7^{\circ} \mathrm{C}$ during the first $10 \mathrm{cy}$ cles), $1 \mathrm{~min}$ at $72{ }^{\circ} \mathrm{C}$, and a final step of $5 \mathrm{~min}$ at $72^{\circ} \mathrm{C}$. The products were analyzed in $1.2 \%$ agarose gel at $80 \mathrm{~V}$, the gels were run for $40 \mathrm{~min}$, visualized with ethidium bromide exposed to UV light, and a 100 bp DNA ladder (Invitrogen) was used as a molecular weight reference to estimate the sizes of the amplification products. The amplified microsatellite products were diluted in a $1 / 40$ proportion (w/w), and $1 \mu \mathrm{l}$ of the dilution, $9.75 \mu \mathrm{l} \mathrm{HiDi} \mathrm{For-}$ mamide and $0.25 \mu \mathrm{lOX}-500$ were added to the mixture. Analysis of this mixture was done on the ABI Prism 3700 (Applied Biosystems) by the fragment analysis method.

\section{3) Analysis of use and conservation value given by stakeholders to Vanilla planifolia germplasm}

We analyzed the value of $V$. planifolia germplasm in two phases: (a) identification of decision-making agents related to use and conservation of vanilla germplasm in the Totonacapan region using the Stakeholder Analysis Method (Grimble 1998) and (b) analysis of value and alternatives of use and conservation among the stakeholders of germplasm cultivated in the Totonacapan region using the Analytic Hierarchy Process (AHP) (Avila 2000) multi-attribute analysis method.

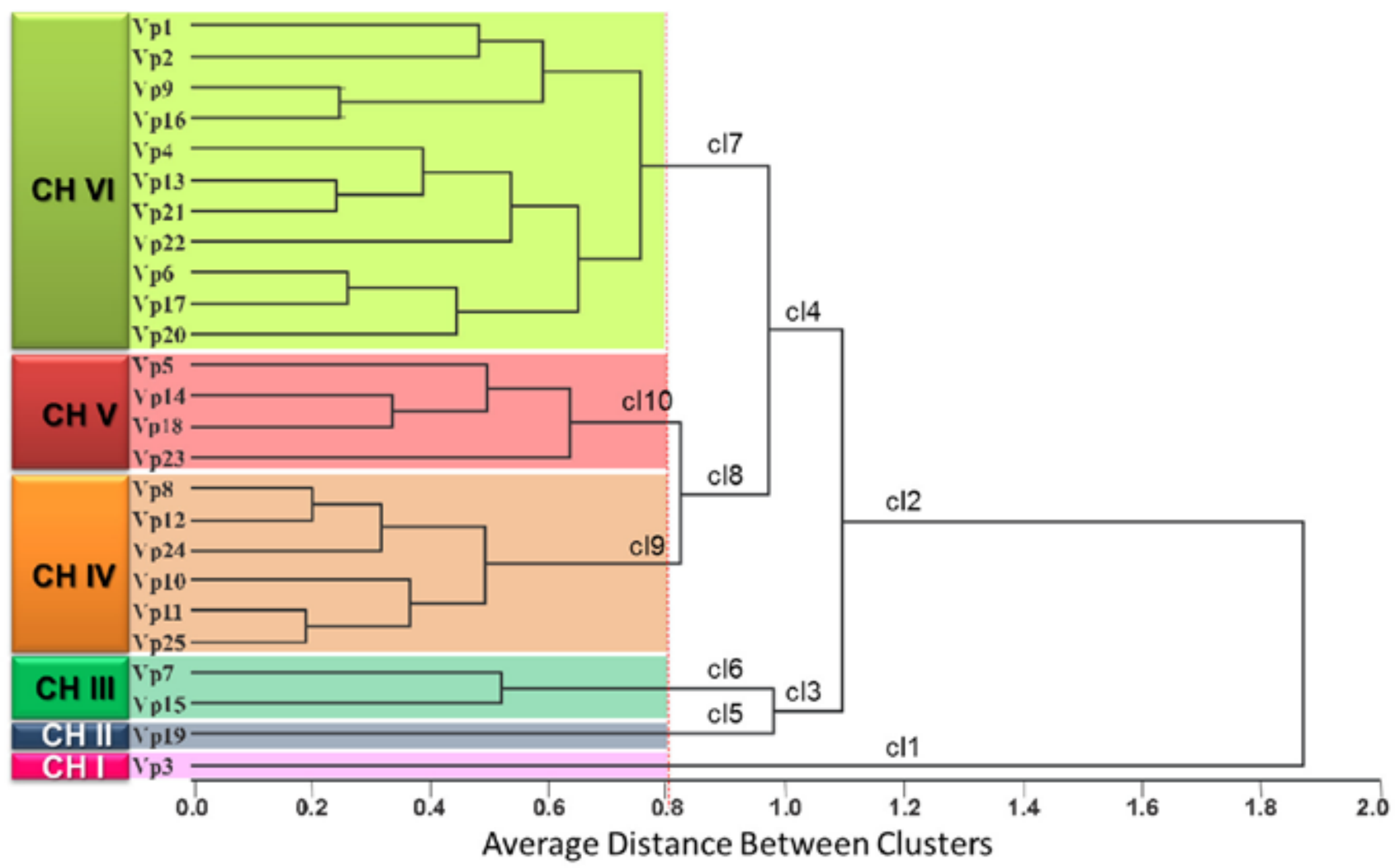

Fig. 1 Dendrogram of 25 accessions of Vanilla planifolia in the Puebla-Veracruz Totonacapan region, based on averages of 10 variables and grouping by similarity distances. Source: Salazar-Rojas et al. (2011). 


\section{4) Strategy design for use and conservation of Vanilla planifolia germplasm in the Totonacapan Puebla-Veracruz region}

The analytical process had two phases: (a) diagnosis, grounded in the livelihood theory (Sustainable Livelihoods Approach; Chambers and Conway 1992) and (b) strategy integration and design, based on the Logical Framework Approach (LFA) (Schmidt 2009).

\section{Results}

\section{1) Chemotypical variation in Vanilla planifolia germplasm}

The results show highly significant $(\mathrm{p}<0.0001)$ differences among the $V$. planifolia accessions evaluated in terms of their aromatic compound content. Using cluster analysis, a total of six chemotypes were identified (Salazar-Rojas et al. 2011; Figure 1). In these chemotypes, it was observed that the vanillin content, which largely defines the dynamics of commercial market quality, is not the trait that has influenced diversity of $V$. planifolia within the Totonacapan region, Mexico.

When the results registered for V. planifolia, V. pompona and $V$. insignis germplasm of the Totonacapan region were compared with data published on $V$. planifolia germplasm from Oaxaca, considered the wildest (least domesticated) material of Mexico (Soto-Arenas 2006; Lubinsky et al. 2008), we detected that proportion of the three minor compounds ( $p$-hydroxybenzoic acid, vanillic acid, $p$-hydroxybenzaldehyde; $M C$ ), relative to the content of vanillin ( $\Sigma \mathrm{MC} /$ vanillin), has decreased in the most commercial collections with vanillin predominating in the aroma. In contrast, in collections with wild characteristics, vanillin has a smaller participation in the aroma, while the minor compounds (MC) are found in a higher proportion, conferring sweet perfumed notes.
Table 1 shows the degree of participation of the three minor compounds (MC) in the aroma of vanilla germplasm in the Totonacapan Region. The species V. pompona and $V$. insignis, considered wild or not cultivated, have the highest values (23 and 16\%), together with $V$. planifolia from Oaxaca (13\%). Cultivated material from the Totonacapan region, in contrast, has a lower proportion of minor compounds in the aroma, oscillating from $12 \%$ in chemotype I, which has "wilder" aromatic characteristics, to $7 \%$ in specimens with highly modified aroma, such as chemotype VI with intense notes of vanillin in the aroma. This reveals that V. planifolia germplasm in the Totonacapan region, Mexico, has undergone a process of selection-domestication guided by sensorial preferences of the Totonaca people, while reproduction by clones has permitted the construction and preservation of chemotypical variation.

\section{2) Analysis of infraspecific genetic variation in Vanilla planifolia}

To confirm whether the chemotypical variation of $V$. planifolia recorded is controlled genetically, 14 microsatellite loci were examined. Of these, 13 were polymorphic and one was monomorphic (Vpl026). A broad range of variation was observed in the polymorphic content index (PCI) from 0.2 (Vpl002) to 0.7 (Vpl005, Vpl016) for the most informative loci, with an average of 0.46 in V. planifolia and lower in V. insignis and V. pompona. During genotypification, no genetically identical individuals were observed.

The number of alleles per locus present in each species and the number of alleles exclusive to a species was variable. The highest number of alleles (44) was observed in the chemotypes of $V$. planifolia, while the lowest number (14) was observed in $V$. pompona. The largest number of exclusive alleles was also found in V. planifolia chemotypes (11) and the smallest number in $V$. insignis and the V. planifolia cultivar "rayada" (1). Heterozygosis observed (Ho) in all of the populations had a high value (0.641) of genetic diversity. For the loci vpl002, vpl005, vpl016 and

Table $1 \mathrm{~V}$. planifolia chemotypes and their main aromatic components of Totonacapan Puebla-Veracruz region and complementary collections. C1: p-hydroxybenzoic acid, C2: vanillinic acid (4-hydroxy-3-methoxybenzoic acid), C3: p-hydroxybenzaldehyde, C4: vanillin (4-hydroxy-3-methoxybenzaldehyde). MC: minor compounds.

\begin{tabular}{|l|c|c|c|c|c|}
\hline \multicolumn{1}{|c|}{ Chemotype } & C1 (ppm) & C2 & C3 & C4 (\%) & IMC/vanillin (\%) \\
\hline V. pompona & 63 & 83 & 104 & 0.1 & 23 \\
\hline V. insignis & 63 & 74 & 128 & 0.2 & 16 \\
\hline V. planifolia (Oaxaca) & 255 & 1315 & 873 & 1.9 & 13 \\
\hline V. planifolia Q I & 127 & 794 & 703 & 1.3 & 12 \\
\hline V. planifolia Q V & $84-112$ & $528-565$ & $413-675$ & $1.1-1.3$ & 10 \\
\hline V. planifolia Q IV & $66-90$ & $391-580$ & $497-600$ & $1-1.4$ & 9 \\
\hline V. planifolia Q II & 86 & 716 & 733 & 1.9 & 8 \\
\hline V. planifolia Q III & $85-100$ & $782-861$ & $344-498$ & 1.7 & 7 \\
\hline V. planifolia Q VI & $58-81$ & $411-755$ & $219-497$ & $1.1-1.8$ & \\
\hline
\end{tabular}

Source: Salazar-Rojas et al. (2011) 


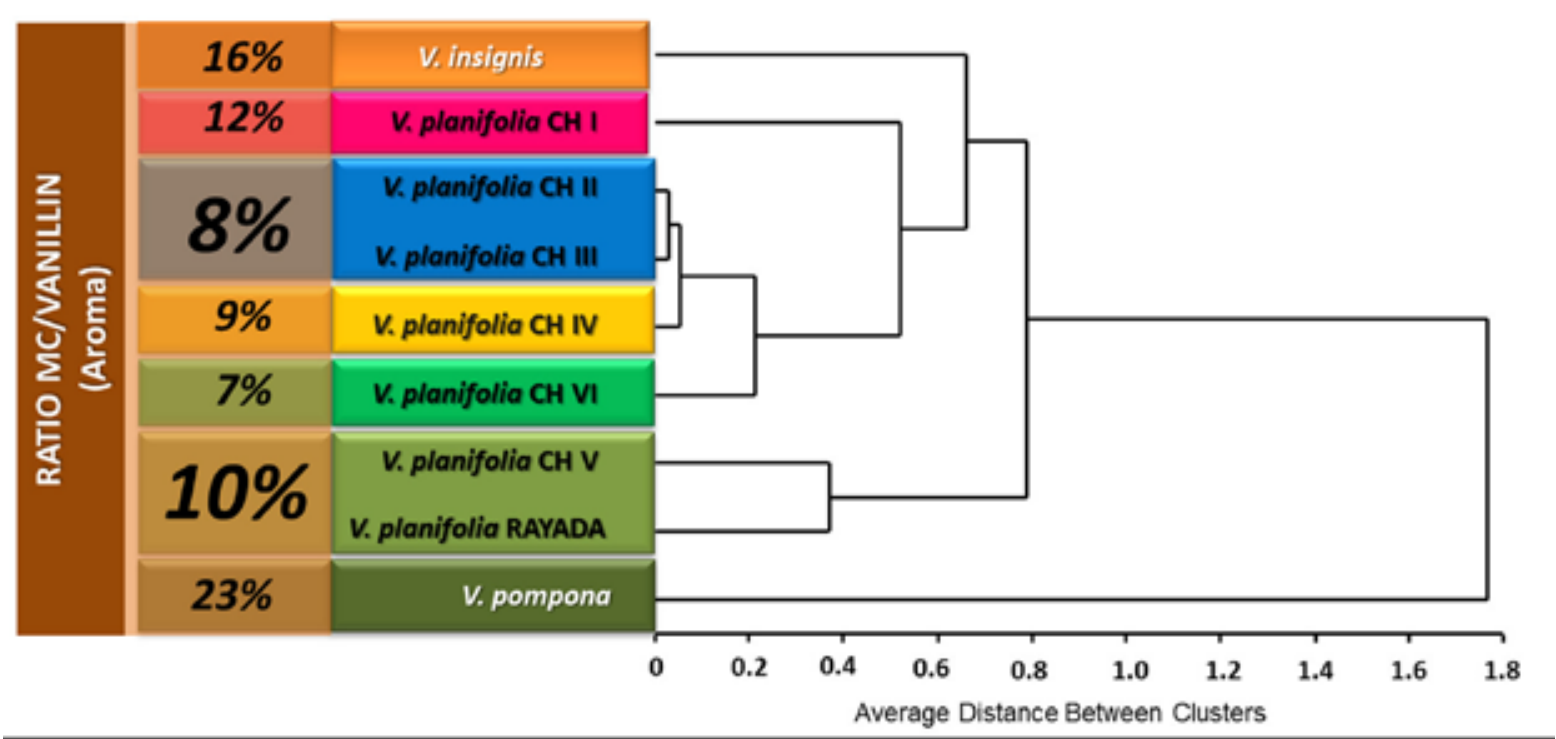

Fig. 2 Dendrogram of Vanilla planifolia collected in the Totonacapan region, Mexico, based on the average of 13 microsatellite loci and grouping by similarity distances. MC: $\mathrm{p}$-hydroxybenzoic acid, vanillinic acid, p-hydroxybenzaldehyde.

vpl047, a deficiency of heterozygotes was found, while for the loci vpl003, vpl010, vpl015, vpl019, vpl022, vpl025, vpl028, vpl031, and vpl050 there was a deficiency of homozygotes. Using the similarity matrix, a UPGMA (Unweighted Pair Group Method with Arithmetic Averages) was performed with SAS 9.1 software, and a dendrogram representing estimated similarities among the analyzed collections was constructed (Figure 2).

Clustering of the collections based on molecular data coincided with the clustering pattern derived from aromatic traits; that is, the genetic groups in the Figure 1 dendrogram correspond to the identified aroma groups (Salazar-Rojas et al. 2011), indicating that chemotypical variation is genetically controlled.

\section{3) Value of the germplasm among the different stakeholders relative to use and conservation of Vanilla planifolia}

Once vanilla germplasm variation was identified and characterized, we analyzed the valuation criteria that guide decision-making of its stakeholders on the use and conservation of the chemotypical and genetic variation of vanilla germplasm of the region. To this end, stakeholders or agents who make decisions concerning use and conservation of vanilla were identified. A total of six groups of stakeholders were determined for the analysis of valuation using AHP: CONAVAI (National Council of Vanilla Growers), merchants, processors, growers, state authorities (Ministry of Development), and academics. We calculated the priorities, indexes of inconsistency, and the synthesis of judgments, using the software Expert Choice V.11.

Using AHP, a group of squared matrixes resulted from the weights stakeholders assigned to each of the four val- uation criteria for the vanilla genetic resource: use value, existence value, information value, and genetic value. We obtained a matrix for each level of criteria and decisionmaking group, as well as a matrix that summarized the weights given by all of the decision-makers. The results of the AHP valuations were analyzed by clusters and the results were integrated into an interaction matrix to identify the chemotypes that most closely matched the profile of each stakeholder group.

Of the six V. planifolia chemotypes, three of them are being conserved by use: the commercially important chemotypes Q4 and Q6 and the genetically relevant Q5. The chemotypes Q1 (biologically important), Q2 and Q3 (commercially significant) are highly endangered; these groups require greater attention in a conservation program.

According to the interest and valuation profile of the stakeholder groups evaluated, groups I and III, composed of CONAVAI and growers, are the candidates with the most favorable characteristics for carrying out a conservation program for all the chemotypes of the region, but especially chemotype I (low commercial potential) because they are highly interested in conserving vanilla varieties and different aromas (Table 2). In the case of chemotypes Q2 and Q3 (high commercial potential), their conservation seems to be more feasible since they are the most used chemotypes. CONAVAI, growers and especially state authorities (Ministry of Rural Development) have expressed interest solely in conserving those materials with commercial potential (Table 2). Although, up to now, conservation of Q5 has not been at risk, the group of stakeholders comprising processors, merchants and academics were highly interested in conserving this germplasm due to its high level of genetic variation (Table 2). 
Table 2 Matrix of interaction between groups of chemotype traits and profiles of stakeholder valuation.

\begin{tabular}{|l|c|c|c|c|c|c|}
\hline \multirow{2}{*}{\multicolumn{1}{c|}{ Stakeholders }} & \multicolumn{5}{c|}{ Chemotypes } & Q6 \\
\hline & Q1 & Q2 & Q3 & Q4 & Q5 & $\checkmark$ \\
\hline CONAVAI & $\checkmark$ & $\checkmark$ & $\checkmark$ & $\checkmark$ & $\checkmark$ & \\
\hline Processors & & & & & & \\
\hline Academics & & & & & $\checkmark$ & \\
\hline Merchants & & & & & $\checkmark$ & $\checkmark$ \\
\hline Growers & $\checkmark$ & $\checkmark$ & $\checkmark$ & $\checkmark$ & & \\
\hline State authorities (Puebla) & & $\checkmark$ & $\checkmark$ & & Biological & Commercial \\
\hline Importance & Biological & Commercial & Commercial & Commercial & & \\
\hline Conservation status & Threatened & Threatened & Threatened & Little concern & Little concern & Little concern \\
\hline
\end{tabular}

\section{4) Design of a use and conservation strategy for Vanilla planifolia germplasm in the Totonacapan Puebla-Veracruz region}

The information generated on aromatic and genetic variation and stakeholder valuation was integrated and analyzed with the Sustainable Livelihoods and Logical Framework approaches.

In the first phase using the Sustainable Livelihoods Approach, a diagnostic of the vulnerability of the vanilla production system of the Totonacapan region was carried out. Three factors were identified: (1) shocks, (2) trends, and (3) temporality (Table 3). The context in which vanilla production in Mexico develops is vulnerable, mainly be- cause of climatic and economic factors. Climatic factors are associated with increasingly intense and frequent hurricanes and tropical storms in the Gulf of Mexico, while economic factors are related to the instability of international prices derived from overproduction at the international level and from the growing interest in the vanilla agro-industry as a profitable strategic activity for numerous developing tropical countries (Table 3). We then identified the five main capitals the region's vanilla production system possesses to confront its vulnerability: natural, social, financial, physical, and human capital.

After the diagnostic, a problem tree was constructed under the Logical Framework Approach. With this tree, we identified the central problem in the use and conser-

Table 3 Summary of the context of vulnerability of the Totonacapan region vanilla production system.

\begin{tabular}{|c|c|c|c|}
\hline Shock & Trend & Temporality & Source \\
\hline Hurricanes and tropical storms & Increasing in frequency and intensity & Since 1988 & SMN 2010 \\
\hline Fusarium spp. & Increasing damage & Since 1988 & The New Scientist 2008 \\
\hline International prices & Speculative behavior & Noncyclic & FAO STAT 2010 \\
\hline International overproduction & Increasing & Since 2004 & FAO STAT 2010 \\
\hline Loss of natural habitat & Increasing & Since 1960 & Del Amo 2008 \\
\hline Low impact agricultural policy & Decreasing state intervention & Since 1980 & Rubio 2007 \\
\hline Loss of local knowledge & $\begin{array}{l}\text { Growing rural-urban outmigration of youth } \\
\text { and breaks in the chain of knowledge }\end{array}$ & Since 1980 & Vergara and Cervantes 2009 \\
\hline
\end{tabular}
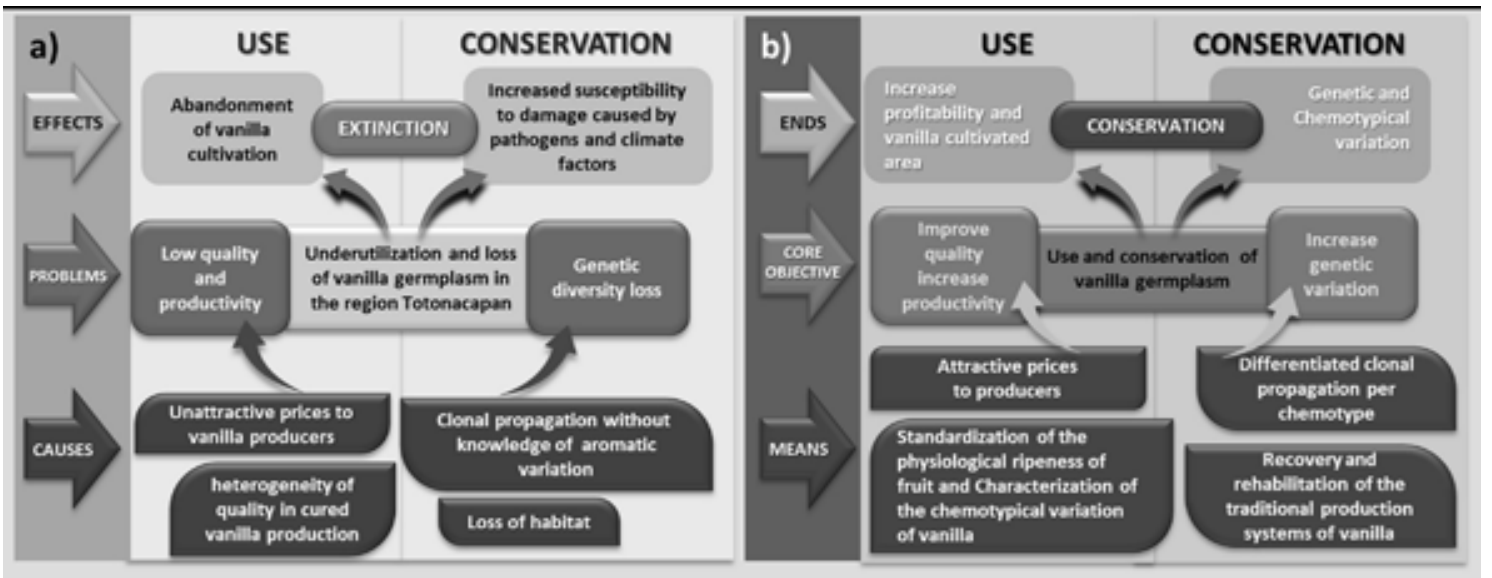

Fig. 3 Problem tree (a) and means and ends tree (b) for designing a strategy of use and conservation of vanilla germplasm in the Totonacapan region. 
vation of vanilla in the Totonacapan region, the causes of the problem, and its effects (Fig. 3a). From the problem tree, a tree of means and ends was deduced to identify the central objective, specific objectives, and alternatives for solution of the problem or intervening actions (Fig. 3b).

Using this format, specific objectives, results and activities were established; these were, in turn, evaluated using a SWOT (Strengths, Weaknesses/Limitations, Opportunities, and Threats) analysis to integrate the proposed strategy for use and conservation of vanilla germplasm of the Totonacapan region, Mexico, aiming to take advantage of the opportunities and strengths, overcome weaknesses and neutralizing threats.

In this way, the following actions were identified: essential role in the conservation and generation of diversity through their use of germplasm, that is, through domestication. This has been the main form of conservation of genetic resources in Mexico. The process began long ago and has not ended; it is still practiced today by millions of farmers who have established a close relationship with their natural surroundings. For these communities, man-plant-environment integration has been the basis of their cultural development (Herrera-Cabrera et al. 2010). This interrelationship has generated complex systems of traditional knowledge that has configured large part of the diversity in Mexico's genetic resources, among which is vanilla (Challenger 1998; Herrera-Cabrera et al. 2010). In the Mesoamerican context, we can say that domestication

General objective: use and conservation of vanilla germplasm of the Totonacapan region

\begin{tabular}{|l|l|}
\hline \multicolumn{1}{|c|}{ Strategies } & Tactics \\
\hline 1) Promote an attractive price to growers & $\begin{array}{l}\text { 1a) Construction of a temporary compensatory payment system for the } \\
\text { productive link in the vanilla chain } \\
\text { 1b) Awareness campaign to promote fair prices for production to strengthen } \\
\text { the vanilla chain }\end{array}$ \\
\hline 2) Reduce heterogeneity in quality of processed vanilla & $\begin{array}{l}\text { 2a) Standardization of physiological maturity of the fruits } \\
\text { 2b) Characterization of chemotypical variation in vanilla }\end{array}$ \\
\hline 3) Differentiated clonal propagation by chemotype & 3a) Differentiated clonal propagation by chemotype \\
\hline $\begin{array}{l}\text { 4) Recovery and rehabilitation of traditional systems of vanilla } \\
\text { production }\end{array}$ & $\begin{array}{l}\text { 4a) Promotion of traditional vanilla production systems as intangible heritage } \\
\text { of humanity }\end{array}$ \\
\hline 5) Breeding program and production technology & $\begin{array}{l}\text { 5a) Genetic and agronomic characterization } \\
5 \mathrm{~b}) \text { Generation of disease resistant clones } \\
5 \mathrm{c}) \text { Generation of a technological package to increase productivity }\end{array}$ \\
\hline
\end{tabular}

\section{Discussion}

Conservation of biological diversity aims mainly to assure maintenance, survival and reproduction of species diversity, especially those that are threatened or in danger of extinction. Like in Mexico, with vanilla clones in the Totonacapan region where wild and cultivated populations are highly vulnerable to extinction, and also in the Soconusco region that has almost a quarter of the orchid species registered in the country and 37 threatened species, many with severely reduced and non-viable populations (Bertolini et al. 2011). Its execution requires a process of identifying actions, objectives and goals that recognize the relationships that exist between the biological and social context of a species in a given region (March et al. 2009). In this way, strategic planning for vanilla conservation is guided toward intelligent investment in firm, timely interventions that effectively confront the causes that affect diversity at any scale, aimed toward obtaining the best results with available resources (Kristensen and Rader 2001).

In the case of vanilla germplasm, there are multiple factors that threaten survival of cultivated populations, particularly the social factor, which also appears to be a determining aspect in the conservation of this germplasm through cultivation. Over time, farmers have played an of plants in traditional production systems has functioned as a very particular model of conservation of numerous genetic resources for hundreds of years.

Conservation through use recognizes authorship of the farmers of a given region and considers the sociocultural context. Genetic variability, evolutionary processes, and biotic-abiotic interactions are also maintained, making it a model that appears to overcome several of the limitations of in situ and ex situ models. For this reason, some authors have theoretically included this form of conservation within a model denominated circa situm (Maxted et al. 1997; Hughes 1998; Frankie et al. 2004).

The term circa situm is used to distinguish the very peculiar species conservation circumstances in traditional production systems (such as home gardens, agroforestry, agricultural, and other systems), in which the species is found outside its natural habitat but within its natural range of distribution. In the particular case of vanilla germplasm of the Totonacapan region, wild populations are unknown and its conservation is thus linked to the Totonaca people who have selected and cultivated biological material of $V$. planifolia in traditional systems of production for at least 250 years (Hágsater et al. 2005; Bory et al. 2007). It is suggested that during this period a domestication process based on aroma was generated, resulting in six chemotypes of vanilla (Salazar-Rojas et 
al. 2011), which are highly important to innovation in vanilla cultivation at an international level. Today, there is more diversity in production systems than in natural landscapes. For this reason and because conservation of $V$. planifolia articulates social, economic and biological elements, because the growers are the agents of conservation, because variation in vanilla germplasm is product of a process of domestication, because its geographic distribution is associated with the presence of traditional systems of production, and because the Totonacapan region is the probable center of diversification of the species, it seems that the best alternative, theoretically and practically, to develop a conservation strategy for the primary genetic pool of vanilla is through the circa situm model, that is, through its use.

The generation of the body of biological knowledge necessary to intervene in vanilla conservation requires the re-interpretation of basic processes such as the ecology of pollination, biology of reproduction, population dynamics, and ecological interactions at the community level in an analysis that recognizes the role of the growers in their sociocultural context as the source of variation in the evolution of vanilla germplasm in the region. Strategic planning for vanilla conservation thus requires a circa situm design that enables us to identify feasible measures, in real scenarios (ecological, economic, social, cultural) that guarantee its protection now but especially also in the long term. It also requires inclusion of rural development of the traditional producer zones as a direct objective of conservation in such a way that competitiveness of the vanilla production system becomes an indicator of the success of its conservation and vice versa. In this sense, the circa situm model of conservation presents itself as a challenge and a scientific alternative for the design of diversity or variation conservation strategies and policies that enable genetic resources such as vanilla to contribute to the development and strengthening of livelihoods in the rural communities that possess the resources.

\section{Conclusions}

The results obtained lead us to conclude the following: Through the study of chemotypical variation in $V$. planiflia germplasm, we identified six chemotypes derived from a complex process of selection-domestication by the Totonacas. During this process, the participation of the three minor compounds, $p$-hydroxybenzoic acid, vanillinic acid and $p$-hydroxybenzaldehyde, has decreased and that of vanillin has increased in the overall aroma.

With the use of microsatellite loci, we related the chemotypical variation identified in $V$. planifolia to infraspecific genetic variation expressed in five cultivated genotypes in the Totonacapan region.

It was observed that, regionally, cultural value is a major stimulus that motivates use and conservation of va- nilla germplasm among stakeholders of the Totonacapan region, together with the monetary benefits obtained by sale of the product. There were four distinct profiles of valuation of vanilla germplasm among the stakeholders, so that the design of conservation proposals should consider identification of the most adequate group of stakeholders for execution of the project.

It was found that chemotypes Q4, Q5 and Q6 are being conserved through their cultivation in the region, while the less cultivated chemotypes Q1, Q2 and Q3 require intervention actions for their conservation.

The germplasm bank safeguarded in the Totonacapan region depends on the future of the culture and traditions of the Totonaca people. Thus, proposals for conservation of vanilla must focus on the development and reinforcement of the Totonaca culture and its traditional production and processing systems.

In center of origin of vanilla, genetic and phytochemical variation exists that is fundamental for the design of a breeding program that would optimize the benefits of the crop for its stakeholders and contribute to conserving the primary genetic pool of Vanilla planifolia J.

\section{Acknowledgements}

This research was supported by Sistema Nacional de Recursos Fitogenéticos (SINAREFI; Clave: BEIVAI-10-5), Fundación PRODUCE Puebla (Addendum No. 1-2009) and by Colegio de Postgraduados (Fideicomiso No. 167304). Victor Manuel Salazar-Rojas is a recipient of a postdoctoral fellowship from the DGAPA-Universidad Nacional Autónoma de México.

\section{REFERENCES}

Avila-Mogollón R (2000) El AHP (Proceso Analítico Jerárquico) y su aplicación para determinar los usos de las tierras El caso de Brasil. Proyecto Regional Información sobre Tierras y Aguas para un Desarrollo Agrícola Sostenible (Proyecto Gcp/Rla/126 /Jpn), Santiago de Chile, Chile.

Bertolini V, Damon A, Natanael A, Veláquez R (2011) Symbiotic germination of three species of epiphytic orchids susceptible to genetic erosion, from Soconusco (Chiapas, Mexico). Eur Sci 1(2): 60-68.

Bory S, Grisoni M, Duval MF, Besse P (2007) Biodiversity and preservation of vanilla: present state of knowledge. Genetic Resources and Crop Evolution 55: 551-571. doi: 10.1007 /s10722-007-9260-3.

Challenger A (1998) Utilización y conservación de los ecosistemas terrestres de México: pasado, presente y futuro. Comisión Nacional para el Uso y Conocimiento de la Biodiversidad. Instituto de Biología de la UNAM y Agrupación Sierra Madre SC, México.

Chambers R, Conway G (1992) Sustainable rural livelihoods: Practical concepts for the 21st century (Medios de vida rurales sostenibles: conceptos prácticos para el siglo XXI). Documento de debate sobre el IDS 296, Brighton: IDS.

Del Amo RS (2008) Paisaje y memoria totonaca: la relación entre ecología cultural y el manejo permanente de los recursos. In: 
Maestre AJ, Casas GAM, González JA (Comp.) Nuevas rutas para el desarrollo en América Latina, Experiencias globales y locales. Universidad Iberoamericana, México, pp 263-302.

FAO STAT (2010) Statistic information for annual vanilla production in Mexico. http://faostat.fao.org/site/567/DesktopDefault .aspx?PageID=567\#ancor.

Frankie GW, Mata A, Vinson SB (2004) Biodiversity conservation in Costa Rica: learning the lessons in a seasonal dry forest. University of California Press.

Grimble R (1998) Stakeholder methodologies in natural resource management, Socioeconomic Methodologies, Best Practice Guidelines. Chatham, UK, Natural Resources Institute.

Hágsater E, Soto-Arenas MA, Salazar Chávez GA, Jiménez Machorro R, López Rosas MA, Dressler RL (2005) Las orquídeas de México. Instituto Chinoín, México.

Herrera-Cabrera BE, Trejo-Miranda J, Delgado-Alvarado A (2010) Conocimiento Tradicional, Predictores Climaticos y Diversidad Genética: Fitoindicadores, observaciones astronómicas y diversidad genética de haba en la agricultura. LAP LAMBERT Academic Publishing.

Hughes CE (1998) Leucaena: a genetic resources handbook. Tropical forestry paper 37. Oxford Forestry Institute.

Kristensen PJ, Rader CJ (2001) The strategic management approach: Practical planning for development managers. Conservation International, Washington, DC.

Lubinsky P (2003) Conservation of wild vanilla, In: Proceedings of Vanilla. First International Congress, Princeton, NJ 08540, New Jersey, USA, November 11-12.

Lubinsky P, Bory S, Hernández HJ, Seung-Chul K, Gómez-Pompa A (2008) Origins and Dispersal of Cultivated Vanilla (Vanilla planifolia Jacks. Orchidaceae). Economic Botany 62: 127-138.

March IJ, Carvajal MA, Vidal RM, San Román JE, Ruiz G (2009) Planificación y desarrollo de estrategias para la conservación de la biodiversidad, en Capital natural de México, Vol. II: Estado de conservación y tendencias de cambio. CONABIO, México, pp 545-573.

Maxted N, Ford-Lloyd BV, Hawkes JG (1997) Plant conservation: the in situ approach. London, Chapman and Hall.

Minoo D, Jayakumar VN, Veena SS, Vimala J, Basha A, Saji KV, Nirmal Babu K, Peter KV (2007) Genetic variations and interrelationships in Vanilla planifolia and few related species as expresses by RAPD polymorphism. Genetic Resources and Crop Evolution 55(3): 459-470. doi: 10.1007/s10722-007-9252-3.

Rubio B (2007) La exclusión de los campesinos y las nuevas corrientes teóricas de interpretación. Nueva Sociedad 182: 21-33.

Salazar-Rojas VM, Herrera-Cabrera BE, Delgado-Alvarado A, Soto-Hernández M, Castillo-González F, Cobos-Peralta M (2011) Chemotypical variation in Vanilla planifolia Jack (Orchidaceae) from the Puebla-Veracruz Totonacapan Region. Genetic Resources and Crop Evolution 59: doi: 10.1007 /s10722-011-9729-y.

Schmidt T (2009) Strategic Project Management Made Simple: Practical Tools for Leaders and Teams. Wiley.

Servicio Meteorológico Nacional (2010) Información histórica de ciclones impactados en México de 1970-2010, Comisión Nacional del Agua (CNA). http://smn,cna.gob.mx/index.php?option $=$ content\&view=article\&id=38\&Itemid $=46($ March 11, 2010).

Sharma A, Verma SC, Saxena N, Chadda N, Singh NP, Sinha AK (2006) Microwave and ultrasound assisted extraction of vanillin and its quantification by high performance liquid chromatography in Vanilla planifolia. Journal of Separation Science 29: 613-619.

Sostaric T, Boyce MC, Spickett EE (2000) Analysis of the volatile components in vanilla extracts and flavorings by solid-phase microextraction and gas chromatography. Journal of Agricultural and Food Chemistry 48: 5802-5807.

Soto-Arenas MA (2003) Vanilla. In: Pridgeon AM, Cribb PJ, Chase MW, Rasmussen FN (eds). Genera Orchidacearum, Vol 3, Orchidoideae (Part 2) Vanilloideae. Oxford University Press, p 402.

Soto-Arenas MA (2006) La vainilla. Biodiversitas 66. Boletín bimestral de la Comisión Nacional para el uso y conocimiento de la biodiversidad. CONABIO, México, pp 1-9.

The New Scientist (2008) World's vanilla supply at threat from disease, Volume 200, Issue 2687.

Vergara TMC, Cervantes VJR (2009) Riesgo, ambiente y percepciones en una comunidad rural totonaca. Economía, Sociedad y Territorio (9): 145-163.

Verpoorte R (2011) Prologue. In: Odoux E, Grisoni M (eds), Vanilla (Medicinal and aromatic plants-industrial profiles). CRC Press.

Wescott RJ, Cheetham PSJ, Arraclough AJB (1994) Use of organized viable vanilla plant aerial roots for the production of natural vanillin. Phytochemistry 35: 135-138. 